\title{
The influence of shale diapirs on turbidite stages distribution in the Cexis, Cantagalo and MassapêFields, Recôncavo Basin, Bahia.
}

\author{
Igor de Andrade Neves, Antonio Fernando Menezes Freire, Wagner Moreira Lupinacci
}

Universidade Federal Fluminense - UFF

\section{Copyright 2019, SBGf - Sociedade Brasileira de Geofísica}

This paper was prepared for presentation during the $16^{\text {th }}$ International Congress of the Brazilian Geophysical Society held in Rio de Janeiro, Brazil, 19-22 August 2019.

Contents of this paper were reviewed by the Technical Committee of the $16^{\text {th }}$ International Congress of the Brazilian Geophysical Society and do not necessarily represent any position of the SBGf, its officers or members. Electronic reproduction or storage of any part of this paper for commercial purposes without the written consent of the Brazilian Geophysical Society is prohibited.

\begin{abstract}
The evolution of geological/geophysical knowledge over the years has discovered new plays in the Recôncavo Basin.Turbidite sandstones of the Caruaçu Member, Maracangalha Formation, of age Middle Rio da Serra are the main reservoirs of the Cantagalo and Massapê fields. The deposition of these turbidites may be had related to the shale diapiric movement around these fields. The origin of shale diapirs in the Recôncavo Basin is interpreted by gravitational instability associated directly and indirectly with tectonism. This study consists in the interpretation of two post-stack 3D seismic volumes in time (PSTM) of the southern portion of the Recôncavo Basin. This interpretation allowed the elaboration of maps and sections to illustrate the shale diapirslocation and their consequences in the occurrence of structural traps or pinch-out sandstones in their flanks.
\end{abstract}

\section{Introduction}

The Recôncavo Basin has been studied since the first half of the $19^{\text {th }}$ century and it can be considered a school basin, due to large number of outcrops representative of its main stratigraphic units. Following its status as one of the main onshore petroleum basins in Brazil, the Recôncavo Basin, together with the Potiguar Basin, were the basins that had the most participation in the bidding rounds for oil and gas exploration and production in Brazil.

Recôncavo Basin is part of an aborted rift and has a stratigraphic succession developed since the Permian, passing by the late Jurassic and ending in the Early Cretaceous (Silva, 2007). Many works have been published about their tectono-sedimentary evolution, sequence stratigraphy and seismostratigraphy, but there are few publications at a reservoir level, especially regarding the production fields.

Horschutz (1969) affirms that the diapiric structures of the Recôncavo Basin forming trends coincident with negative gravimetric alignments, and that the shale diapiric movement can only be triggered by unable in the distribution of lithostatic charge on the plastic layer.

However, once the diapirismis initiated, the lithostatic unbalance is increased by the increasing counter- attraction effect, which accelerates the ascending movement of diapiric material, thus he concludes that the formation of gravitational instability is due to a combination of lithostatic charge unbalance and appearance of a positive counter-attraction.

The aim of this work is to better understand the tectonosedimentary formation of shale diapirs and consequently the distribution of turbidities reservoirs of the Late Cretaceous of the Caruaçu Mb.,Maracangalha Fm., in the Cexis, Cantagalo and MassapêFields.

The study area is located at a NW step from the structural low named Camaçari Low, what is the main oil and gas generation kitchen in the southern compartment of the Recôncavo Basin (Fig. 1).

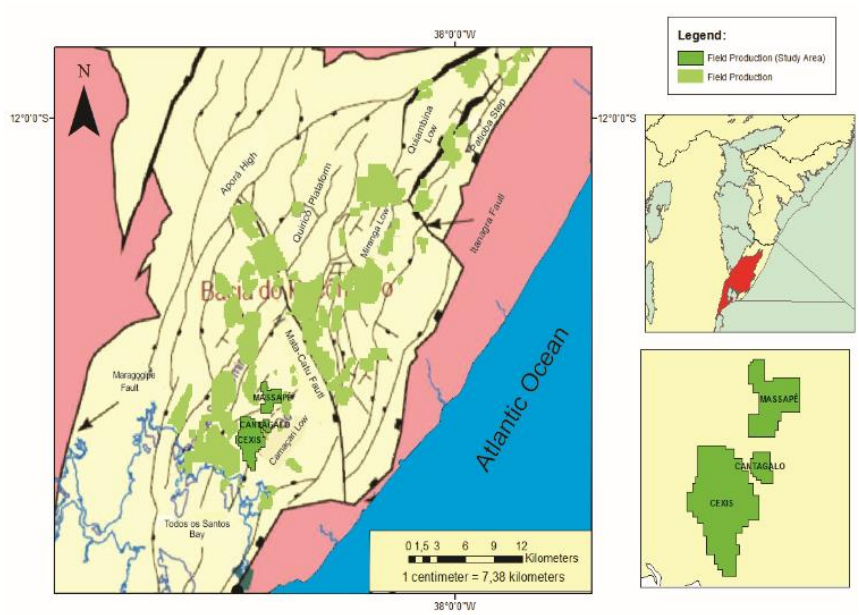

Figure 1. Location map of the study area at the Recôncavo Basin. Modified from Milhomemet al.(2003).

\section{Materials and Methods}

Two 3D PSTM volumes (Cantagalo and Cexis) and 16 wells, located in the southern compartment of the Recôncavo Basin, were used in this study. The seismic data covers an area of approximately $220 \mathrm{~km}^{2}$, has a maximum penetration of 4 seconds two-way travel time (TWTT), and covers all the Cexis, Massapê and Cantagalo oil/gas fields (Figure 2).

In Cantagalo and MassapêFields, the main reservoirs are turbidite stages composed of sandstones filling throughs and sealed by slurries, siltstones and shales of the Maracangalha Fm. - Upper Rio da Serra (Freire et al. 2018; Freire et al., 2019), while in the Cexisfield the principal reservoir are turbidites sealed by shales of the Candeias Fm. - Lower Rio da Serra (ANP, 2018). 
THE INFLUENCE OF DIAPIRISM ON THE RESERVOIR DISTRIBUTION

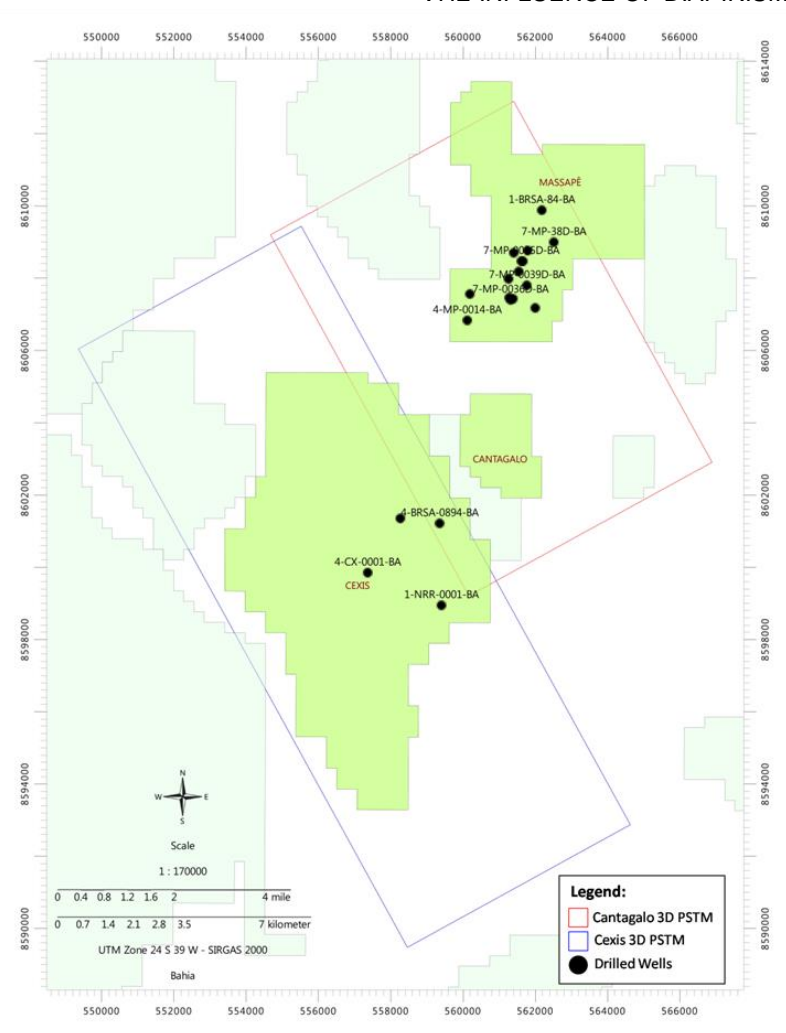

Figure 2:Map of the study area showingthe Massapê, Cantagaloand CexisFields, seismic surveys and well locations.

Seismostratigraphy interpretation was aided by the seismic attribute analysis, such as instantaneous amplitude, phase and frequency (Payton, 1977), which provided the identification of stratigraphic terminations and reflectors continuity. Firstly, the structural smooth attribute was used to remove noise and increase the continuity of seismic reflectors, observing an improvement in seismic image quality for interpretation (Figure 3-b).

The amplitude RMS was calculated from the structural smooth, which computes the square root mean of the amplitudes, the bias removal was used to remove bias deconvolution of the seismic traces and finally the $80^{\circ}$ phase rotation was used to create the appearance of pseudo-revealing (or TecVA) (Figure 3-C).It was important in the structural mapping of the top of the basement and the main faults, as well as the delimitation of shale diapirs.

The interpreted horizons allowed the elaboration of geological maps and sections, illustrating the arrangement of the subsurface layers in the region. Figure 4shows the workflow used in this work.
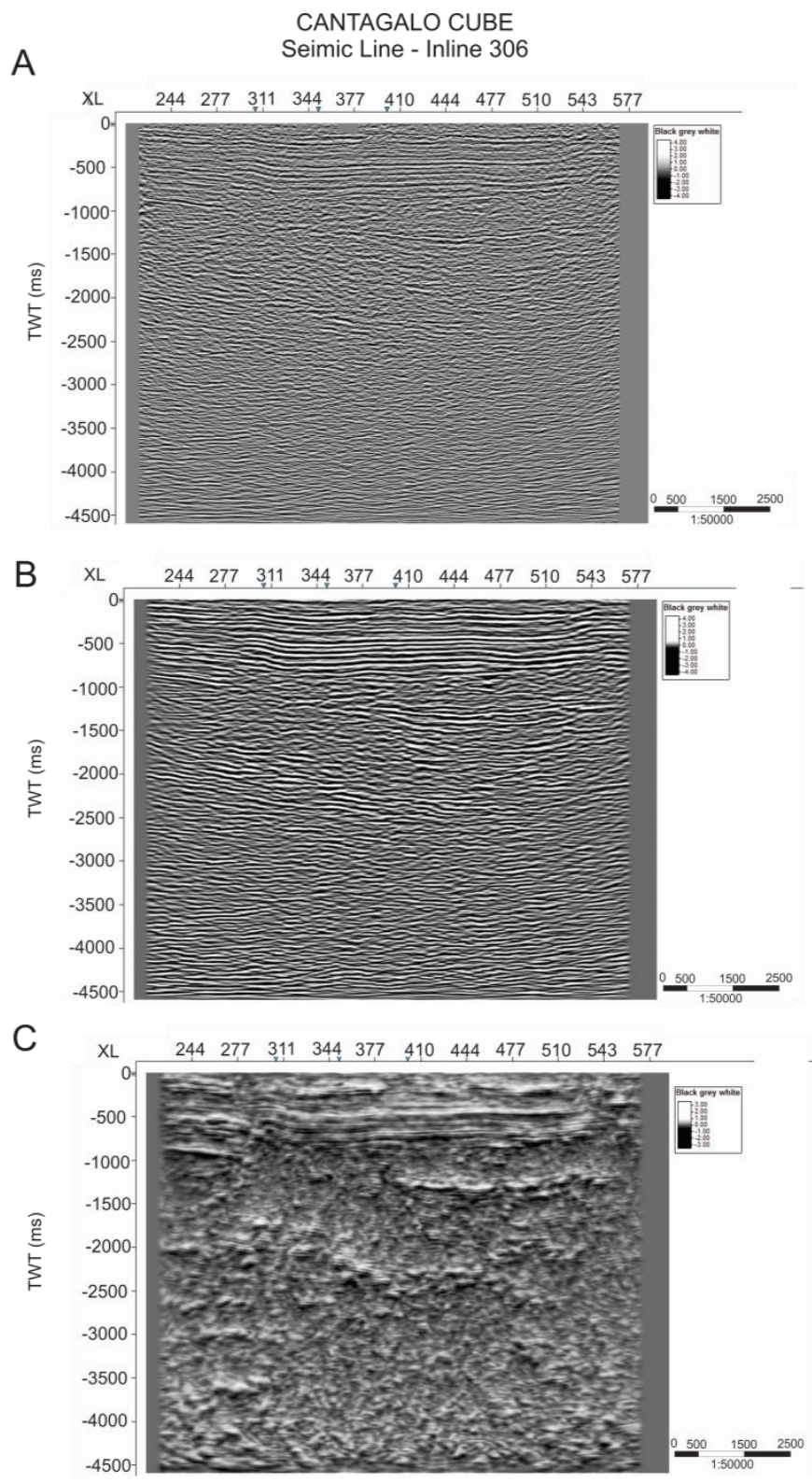

Figure 3:Section 306: (a)original amplitude; (b) structural smooth attribute; and (c) TecVa attribute. 
NeVES, I.A.; FrEIRE, A.F.M.; LUPINACCI, W.M.

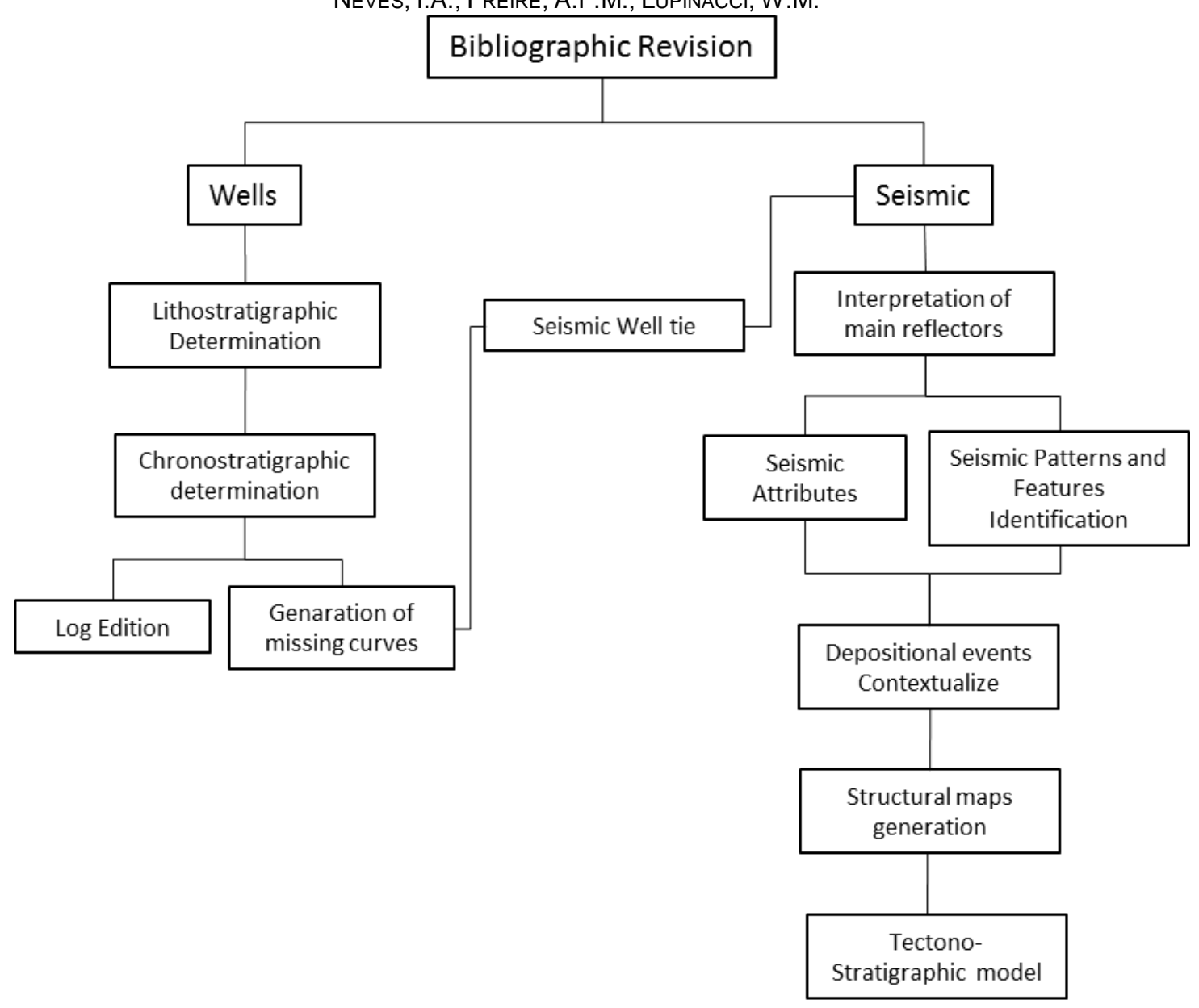

Figure 4: Workflow used in this work.

\section{Results and Discussion}

Sequences of second order were interpreted, where the deposits of the syneclise, pre-rift and syn-rift phases were identified according to their seismic characteristics. Structural features like faults were mainly observed in the pre-rift section. The first interpreted reflectors represent the basement, here not individualized from the syneclise (Permian) phase. None of the wells in the study area reached the basement, being its interpretation based only on the seismic data.

The basement has a chaotic internal reflector pattern, its upper limit is given by the Upper Jurassic unconformity (Silva 2007), which separates it from the pre-rift section, this presents patterns of plane-parallel reflections of good continuity. The basement structural framework is defined by normal, high-angle synthetic and antithetic faults, oriented mainly in the NE-SW and N-S (Figure 5)

The package overlying the basement presents reflectors of high amplitude and good continuity of tabular geometry, with seismic thicknesses greater than 500 ms. The lower limit of this package is given by the crystalline basement and the upper limit is an unconformity that marks the beginning of the sedimentary section.
The sedimentary deposits, deposited from the LateJurassic (Dom João Stage) to the Neo-Cretaceous (Eoberriasian), are intercept by post-depositional normal high angle faults and are arranged in horst and grabens (Figure 6).

The boundary between the pre-rift and the syn-rift phases has been the subject of discussion (Magnavita, 1996; Da Silva, 1996). Da Silva $(1993 ; 1996)$ attributed that the Água Grande Fm. was deposited during the rift phase, while Caixeta et al. (1994) and Magnavita (1996), among others, relate the beginning of the rift to the regional transgression composed by lacustrine shales of the Tauá $\mathrm{Mb}$. that overlaps the eolic sandstones of the Água Grande Fm. This transgression would be related not only to a probable climatic humidification, but also to an increase in subsidence rates, with rupture of the crust still under moderate tectonic activity.

The shale deposits of the Gomo Mb.,Candeias Fm., according to Aragão (1994), represent the initial phase and deepening of the paleo-lake during the Middle Rio da Serra (Eoberriasian / Eovalanginian), when the Recôncavo Basin developed a physiography characterized by relatively stable platform areas and depocenters with high subsidence rates. 
THE INFLUENCE OF DIAPIRISM ON THE RESERVOIR DISTRIBUTION

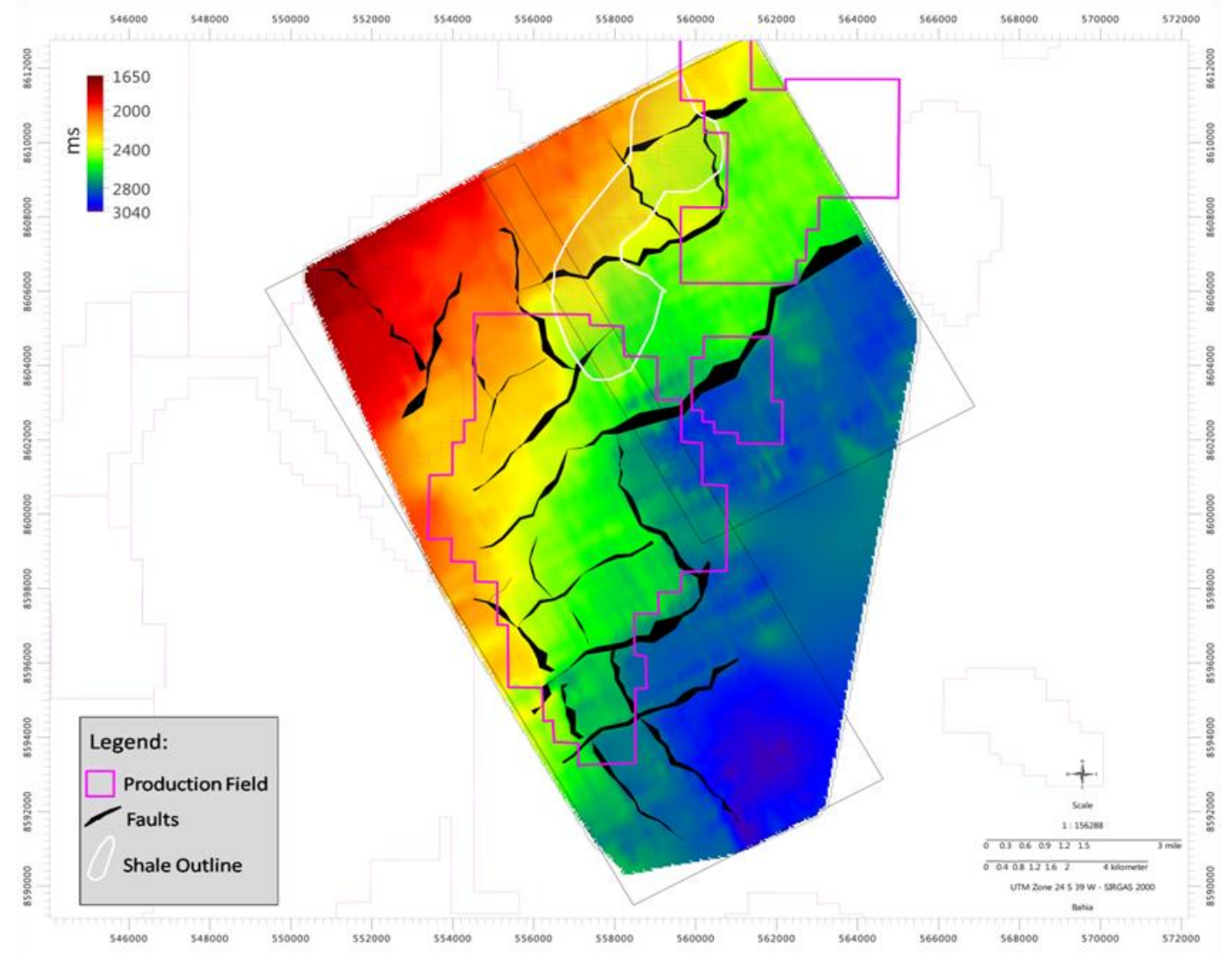

Figure 5: Structural map in time of the basement. Shale diapir outline is highlighted by the white line.

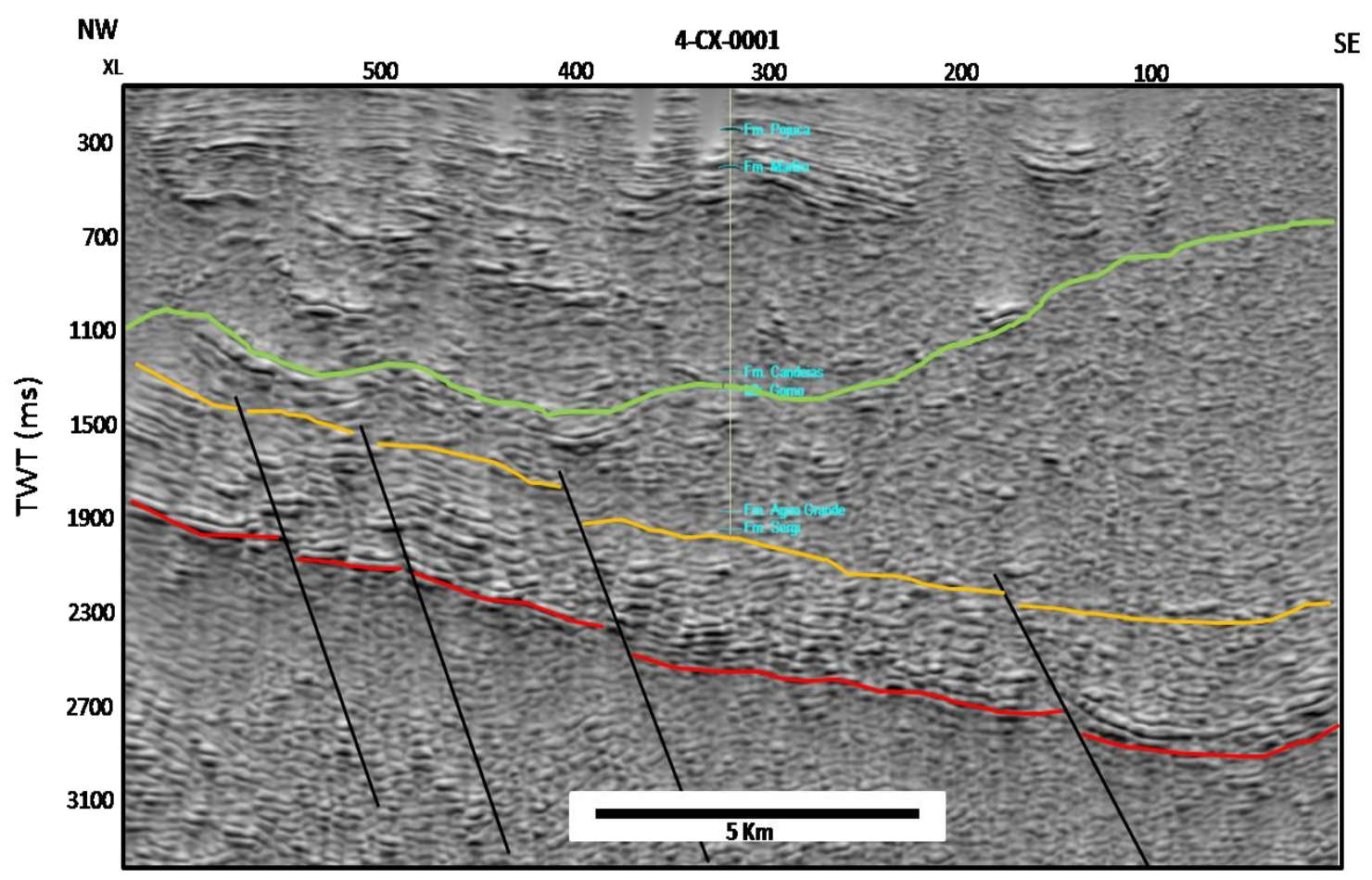

Figure 6:Seismicsection showing interns seismic reflections in the pre-rift section.Top of the basement (red), pre-rift -section (orange), andCandeias Fm. (green). 
The base of the Gomo Mb. is marked by a strong positive reflector, while the top of the Gomo Mb. is not well marked seismically, probably due to the lack of contrast between the shales of the Maracangalha and Candeias Formations.

In the Cantagalo seismic volume (which covers the Cantagalo and Massapê Fields) is possible to observe large dome shaped structures, varying with seismic times of $120 \mathrm{~ms}$ (TWT) in their shallower portion in the western part of the Massapê Field. In the structural interpretation is observed the existence of pronounced depressions, such as that situated in the central part, with 1950ms (TWT), forming a through (Figure 7).

It has not yet been possible to accurately individualize the probable cause for the unbalance that motivated the beginning of the shale movement to form the diapirs; they may have been: differential compaction, subsidence differential and/or faults.

Some authors infer that the weight of the lithological column overlying the shales of the Gomo Mb.,Candeias Formation (Middle-Rio da Serra), has been a strong contributor to the formation of the diapirs. However, it is worth mentioning that the orientation of the diapirs in the area is the same that the orientations of the main faults that control the basement (Figures 5 and 8), leading to the belief that the alignments of the diapirs may be related also to the basement and the pre-rift section tectonics.

The uplift of the shale diapirs was responsible for the depositional direction of the turbidites reservoirs of the Maracangalha Fm. (Middle-Rio da Serra), which are the main reservoirs of theCantagalo and MassapêFields and secondary reservoirs in the Cexis Field.

This throughis associated with the diapirism and could have affected the distribution of turbidite reservoirsof the Caruaçu Mb. (Maracangalha Fm.). One possible model is that the deposition of these turbidites in the system was occurred by the elevation of shales controlling their distribution.

It is important to note that the deepest area in thethrough is in the Northern partof the study area. The through is down-dip to the North, that it could be open a new interpretation for the direction of turbidite flows, from the South to the North.

In the Cexisseismic volume, the continuity of the diapiric features is more regular. It is possible to notice the extension of the trough entering the field in the central part, but not having the same range as in the northernmost portion (Figure 8).

The shale diapirs of the Candeias Fm. have seismic time varying from $600 \mathrm{~ms}$ to $1900 \mathrm{~ms}$ (TWT). The shallowest part of the shales lies to the North and East of the Cexis Field. There are outcrops of theCandeias and Maracangalha Formations related to diapirs at the East of the Cexis Field.

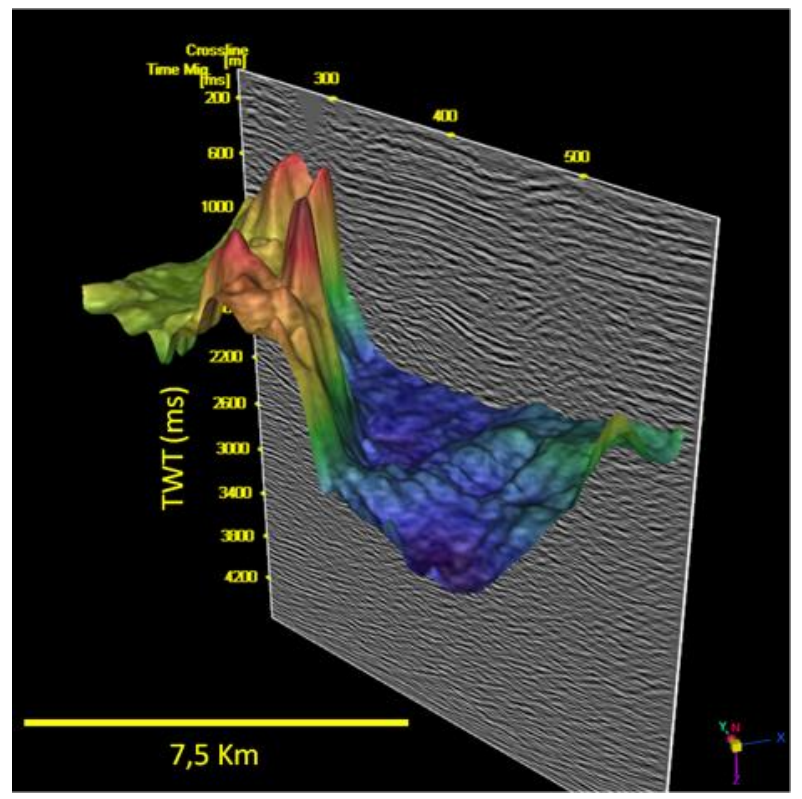

Figure 7: 3D view of the Gomo Member evidencing the through.

In the seismic structural map in time on the top of the Candeias Fm. is observed two large diapiric features with NE-SW alignment (Figure 5). These structures have the same alignment of the main faults of basement, which could be suggest some structural control as another factor in the diapirs formation (Figure 6).

The correct identification of the walls of shale diapirs becomes very difficult, due to the seismic imaging of the region.Therefore, the diapir wall can contain variations that increases and compromises the risk in the exploration of this exploratory play.

\section{Conclusions}

The seismic interpretation allows the identification of shale diapirs at the western portion of the MassapêField, separating from the Norte Fazenda Caruaçu Field, and at the norther portion of the Cexis Field.The through formation occurs due to shale flowage and the consequent evolution of shale diapirs of the Candeias Formation. Their understanding still needs to be evaluated more, andthe tectonic influence in the evolution and formation of the diapirs could be inferred, since the diapirs have the same structural trend of the faults that affect the pre-rift section and the basement. The main reservoirs of the Massapê and Cantagalo Field were deposited within the through.This through is not very expressive in the Cexis Field, limiting itself in the Northeast part of thisfield. Diapirism was the one of the most important events that controlled the distribution of the Caruaçu reservoirs. Another discussion that is being evaluated is the possibility that the turbidite flows occurred from South to North.The seismic attributes, especially the TecVA and the structural smooth, were fundamental in the structural mapping of the top of the basement and the main faults in the seismic sections, as 
well as in the definition of the shale diapirs and the interpretation of unconformities.Other seismic attributes are being studying for improving the seismic interpretation with main objective to understand the distribution of Caruaçu beds and the turbites flow.

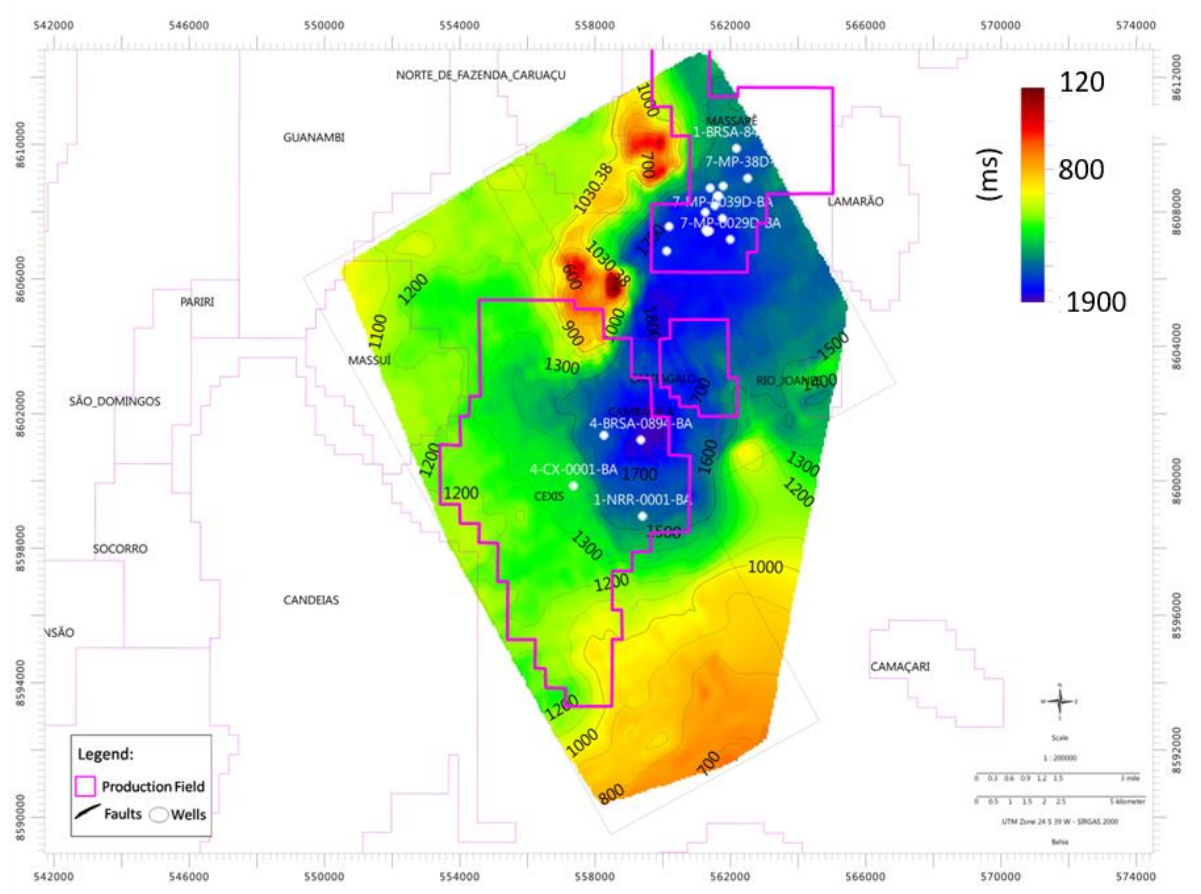

Figure 8:Structural map in time on the top of the Gomo Mb, Candeias Fm.

\section{Acknowledgments}

The authors thank Petrobras for financial support and to the Agência Nacional do Petróleo, Gás Natural e Biocombustível (ANP) for providing data for this research.

\section{References}

ARAGÃO, M. A. N. F.; PERARO, A. A. Elementosestruturais do rifte Tucano/Jatobá. In: SIMPÓSIOSOBRE O CRETÁCEO DO BRASIL. 3., 1994, Rio Claro.Boletim do... Rio Claro: Universidade EstadualPaulista, 1994, p. 161-165.

CAIXETA, J. M.; BUENO, J. V.; MAGNAVITA, L. P.; FEIJÓ, F. J. Bacias do Recôncavo, Tucanoe Jatobá. Boletim de Geociências da Petrobras, Rio de Janeiro, v. 8, n. 1, p.163-172,jan./mar. 1994.

DA SILVA, N.M. 1993. Flooding surfaces, depositional elements and accumulation rates - characteritcs of the Lower Cretaceous Tectonosequence in the Reconcavo Basin, northweast Brazil. Ph.D. Thesis, University of Texas, $312 \mathrm{pp}$.

DA SILVA, N.M. 1996. Paleocorrentes deposicionais na Formação Sergi. Boletim Técnico da Petrobrás, v.9, n.2, p.181209.

FREIRE, A. F. M .; LUPINACCI, W. M.; PEQUENO, H.C.; SANTOS, G. F. R.; RAMOS, M.M.; NEVES, I.A.; LEONE, Y.; SILVA, C. F.. High resolution stratigraphy in 3rd and 4th order turbiditic stages of the Caruaçu Member of the Maracangalha Formation, Campo de Massapê, Recôncavo Basin - BA. Presentation 49th Brazilian Congress of Geology, 2018.
FREIRE, A. F. M .; SANTOS, G. F. R.; SILVA, C. F.; PEQUENO H.C.; LEAL, I. P. M.; LUPINACCI, W. M.; ÁVILA, R. S. F.. High resolution stratigraphy using well logs to identify turbidite stages in the Massapê oil field, Recôncavo Basin, Brazil. 16th International Congress of the Brazilian Geophysical Society.

HORSCHUTZ, P. C. TEXEIRA, A. A. - 1969 - Diapirismo de folhelho na Bacia do Recôncavo o. Boletim Técnico da Petrobras, 12 (3), Rio de Janeiro.

MAGNAVITA, L.P. (1996). Estruturas e tectônica das coberturas do Estado da Bahia. Mapa Geológico do Estado daBahia - Texto Explicativo. p. $239-259$.

MILHOMEM, P.S.; DE MAMAN, E.J.; OLIVEIRA, F.M.; CARVALHO, M.S.S.; SOUZALIMA, W. Bacias sedimentares brasileiras: Bacia do Recôncavo (2003). Phoenix. Ano 5, n. 11.

PAYTON, C.E., ed., 1977, Seismic Stratigraphy - Application to Hydrocarbon Exploration: American Association of Petroleum Geologists Memoir 26, The American Association of Petroleum Geologists, Tulsa, $516 \mathrm{p}$.

SILVA, O.B., CAIXETA, J.; MILHOMEM, P.S.; KOSIN, M. Bacia do Recôncavo. Boletim de Geociências da Petrobrás, v. 15, n. 2, p. 423-43, 2007.

http://www.anp.gov.br/images/planos_desenvolvimento/Massape .pdf

http://www.anp.gov.br/images/planos_desenvolvimento/Cantagal o.pdf

http://www.anp.gov.br/images/planos desenvolvimento/Cexis.pdf 